\title{
Discussion on the Construction of Agricultural E-commerce Mode
}

\author{
Jia Huiting \\ Xinyang Vocational and Technical College, Xinyang, Henan, China \\ *email: jiahuiting@126.com
}

\begin{abstract}
With the rapid development of agricultural industrialization and agricultural informatization, the impact of e-commerce on agricultural economy is becoming more and more important. It brings new features such as high efficiency, low cost and no limitation of time and space to agricultural development. The majority of farmers and agricultural enterprises on the e-commerce platform is very urgent demand, select and build the appropriate e-commerce model to become the top priority of agricultural economic development. This paper tries to explore the development path and construction principles of agricultural e-commerce model by analyzing several typical patterns of current agricultural e-commerce, namely, B2B, F2C, F2A2B, O2O, etc., in the construction of agricultural e-commerce model. In order to promote agricultural e-commerce to provide a better development.
\end{abstract}

Keywords: Agriculture, e-commerce, model, development.

\section{Introduction}

Agriculture is the oldest industry of mankind and plays a fundamental role in the three industries of the country. At present, China's agricultural development has entered a new historical period, grain production to achieve "Twelve increased", but difficult to buy and difficult to sell the situation does not ease. On the one hand, the "garlic you ruthless", "Jiang your army" and other phenomena occur frequently, on the other hand, many high-quality agricultural special products due to poor information and other reasons serious slow-moving, and even decay discarded. E-commerce as a new era of rapid rise, "Internet + " for two consecutive years into the government work report, the development of agricultural e-commerce in the ascendant. The central and local governments have issued a series of policies and measures to encourage the development of e-commerce in agriculture, and actively promote the rapid development of agricultural e-commerce. At this stage, how to let the agriculture plug in the "Internet + " wings, how to choose and construct a model of agricultural e-commerce and a series of issues become an important issue in the development of agricultural e-commerce.

Agriculture is the oldest industry of mankind and plays a fundamental and fundamental role in the three industries of the country. At present, China's agricultural development has entered a new historical period, grain production to achieve "Twelve increased", but difficult to buy and difficult to sell the situation does not ease. On the one hand, the "suan ni hen", "Jiang ni jun" and other phenomena occur frequently, on the other hand, many high-quality agricultural special products due to poor information and other reasons serious slow-moving, and even decay discarded. E-commerce as a new era of rapid rise, "Internet +" for two consecutive years into the government work report, the development of agricultural e-commerce in the ascendant. The central and local governments have issued a series of policies and measures to encourage the development of e-commerce in agriculture, and actively promote the rapid development of agricultural e-commerce. At this stage, how to let the agriculture plug in the "Internet + " wings, how to choose and construct a model of agricultural e-commerce and other series of issues become an important issue in the development of agricultural e-commerce. 


\section{The Significance of Developing Agricultural E - Commerce}

With the sound information network and the popularity of Internet technology, agricultural information technology and the contribution rate of a substantial increase in the transformation of traditional agricultural production has become a top priority. As the advanced form of the development of agricultural information, agricultural e-commerce has become the only way to promote agricultural scale, characteristics, industrialization and modernization.

\subsection{This Is the Needs to Achieve the Agricultural Economy Across the Development}

E-commerce is based on the new productive forces, through the Internet to build a variety of business platform will be linked individuals and individuals, businesses and businesses, individuals and enterprises closely to promote large-scale enterprise concentration, gathering, resulting in intensive large benefit space, to promote the agricultural economy from extensive to intensive, and from the epitaxial to the content-type change. Whether developed areas or underdeveloped areas, the development of agricultural e-commerce for the transformation of the extensive significance of the extraordinary traditional agriculture.

\subsection{This Is the Need to Accelerate the Flow of Agricultural Information}

At present, the circulation of agricultural products is not smooth. The key problem is that the production and management of the small-scale peasant economy are incompatible with the big market and large circulation. Because of the information occlusion, information not working, largely caused by many local agricultural production and marketing out of line, leading to high-quality agricultural products cannot output. The introduction of e-commerce to agricultural production can give full play to its global and inclusive characteristics, so that farmers and enterprises to keep abreast of market information, and effectively reduce agricultural production risks.

\subsection{This Is the Need to Broaden the Agricultural Marketing Channels}

From the sale of agricultural products, the current is mainly limited to the traditional spot transactions. The modern large-scale agricultural trade market is still underdeveloped, short-term contract transactions, order forms of transactions is lacking, there are narrow channels of agricultural products, links are complex, serious supply and demand chain and other issues. Relying on the Internet fast, direct and effective delivery of information for the supply and demand sides to provide contact, trade, e-commerce platform, help to achieve the scale of agricultural products circulation, organization, thus broadening the sales channels of agricultural products, supply and demand sides to obtain tangible benefits.

\subsection{This is the need to promote agricultural industrialization process}

Agricultural e-commerce to agricultural production of prenatal, mid-term, post-natal and many other aspects of organic combination, can eliminate the contradiction between agricultural production and market information asymmetry. This plays a key role in improving the agricultural value chain and enhancing agricultural competitiveness. This mode not only improved the degree of organization of agriculture, promoted the adjustment of agricultural production structure, but also solved the circulation problem of agricultural products, promoted the specialization division of labor in rural areas and coordinated development of related industries, which greatly promoted the industrialization of agriculture.

\section{The Route Choice of Agricultural E - Commerce}

Agricultural e-commerce to the traditional agricultural development model has brought a certain impact. Due to the special production cycle and storage time of agricultural products, agricultural enterprises or individual farmers can plan and select the appropriate sales channels and e-commerce models according to their actual conditions such as products, capital, technology, human resources and logistics.

\subsection{Business to Business (B2B) Model}

B2B model is mainly applied to specialized in agricultural production, processing and marketing of large enterprises and leading enterprises to carry out e-commerce activities. 
In the B2B e-commerce model, the leading agricultural enterprises or well-known enterprises through self-built e-commerce platform, the chain from the entire agricultural chain, the supply chain upstream and downstream enterprises with the platform to achieve the agricultural information search, negotiation, currency settlement, The choice of logistics enterprises such as the formation of the entire online trading system. In the production process, these leading agricultural enterprises can implement large-scale, standardized production, agricultural production and quality are good; In the sales process, these well-known agricultural enterprises have high brand credibility, and the platform of electric business is mature, and they can publish information and advertise online at any time through the Internet. In the circulation, these agricultural enterprises generally have their own distribution sector, to timely delivery of agricultural products to customers, or relying on third-party logistics enterprises; in the payment process, buyers and sellers have set up online banking companies, through the Internet on the transfer to ensure the smooth completion of the transaction.

\subsection{Farmer to Consumer (F2C) Model}

F2C model is an e-commerce model developed between farmers and consumers. The model combines the $\mathrm{B} 2 \mathrm{C}$ and $\mathrm{C} 2 \mathrm{C}$ business model, where Farmer can be a single farmer, family farmer, can also be small and medium-sized agricultural sales enterprises, with e-commerce platform will be directly sold to consumers of agricultural products. Farmers themselves or agricultural production enterprises, through self-built website or in the Amazon, Tianmao, Jingdong, The original life, Every day orchards and other third-party e-commerce platform to open shops, real-time release of agricultural products for sale information. And customers are directly from these electronic business platform to search out their own agricultural and sideline products, and online with farmers or agricultural products sales business transactions. Finally, farmers or agricultural marketing enterprises through the self-built or third-party logistics platform will be distributed to consumers in the hands of agricultural products. As the core of the agricultural industry chain trading, F2C model requires the creation of agricultural products shop business, be sure to choose the right site construction service providers, focusing on how to allow users to search, comparison, the process more convenient, tailored for their industry, products And brand-style personalized marketing-type site. Such as Yangcheng Lake City, Suzhou City, the famous "Taobao Village" to "crab second generation of new farmers" as the leading crab farming and traditional aquaculture company integration of Taobao operating mode, has opened Taobao shop More than 500, with annual sales of nearly 400 million yuan, effectively improving the town's entrepreneurial employment environment, and promote the rapid development of the local economy.

\subsection{Farmer To Association To Business (F2A2B) Model}

This is a new agricultural e-commerce model composed of $\mathrm{F}, \mathrm{A}, \mathrm{B}$, which $\mathrm{A}$ is the Association, representing agricultural professional cooperatives or agricultural associations, the future will be a new type of agricultural consortium. F2A2B model is reflected in the production of agricultural products in the production process, as farmers and agricultural enterprises related to agricultural cooperatives or agricultural associations. Through the timely understanding of agricultural market supply and demand information or business order information, organization of farmers to produce specific agricultural and sideline products. The use of the Internet to buy seeds, fertilizers and other agricultural materials, the appointment of agricultural technical personnel to the scene to guide and guide the work of farmers, and even the establishment of agricultural products traceability system in order to agricultural products from production to harvest the entire stage of quality and standards to control, Thereby enhancing the market competitiveness of agricultural products. Second, in the sales process, agricultural cooperatives or agricultural associations on behalf of all farmers and agricultural products related businesses through e-commerce platform for negotiations, contract and online transactions. These intermediary organizations can both self-built Web site can also shop in a third-party platform, and new, distinctive agricultural products sales site generally attract more customers, such as Amazon, Taobao, Jingdong and some platform for local specialties are very a good choice. Finally, in the distribution process, agricultural cooperatives or agricultural associations can according to the different needs of consumers, classification, packaging of various types of agricultural products, and through self-built logistics or third-party logistics companies, agricultural 
products will be the first time sent to consumers. In this reverse mode from demand to production, agricultural cooperatives or agricultural associations play a third-party market role, which not only ensure the interests of farmers, so that farmers are no longer blind production, but also to speed up the process of agricultural industrialization.

\subsection{Online to Offline (O2O) Model}

This is a special form of $\mathrm{B} 2 \mathrm{C}$, which realizes the online trading and offline experience of the organic integration, so that the Internet has become the forefront of offline transactions. In the $\mathrm{O} 2 \mathrm{O}$ platform business model, the online platform to provide consumer guide, offer information and sharing platform, and offline businesses are focused on providing services. $\mathrm{O} 2 \mathrm{O}$ model in the field of agriculture as the main performance: farmers or agricultural production enterprises in addition to the use of e-commerce platform for high-quality agricultural products to the consumer delivery of the designated location. But also to guide online customers to the physical store to buy agricultural and sideline products, so that customers enjoy the online discounted prices at the same time can enjoy the next line of personal services and word of mouth with the rapid spread of mass effects in the short term consumer resources. $\mathrm{O} 2 \mathrm{O}$ agricultural e-commerce model so that farmers and agricultural production enterprises on the city's physical stores greatly reduced dependence, just under the online orders will be sent directly to customers in agricultural and sideline products, which also saves part of the marketing costs. In addition, the "Internet + leisure agriculture" is also the O2O model in the agricultural field of the common form. Such as the country's first professional rural tourism website platform and mobile APP-to farm network, through the city around the farm music, orchards, nurseries, fishing grounds, residential and ecological park integrated into an integrated service platform. This is the first to solve the "family to farm" choice, and then after consumption and experience, but also led the "farm into the family" for the general public to solve the demand for green, healthy food.

\section{Some Enlightenments of Developing Agricultural E - Commerce}

Facts show that, although through the Internet transactions can reduce agricultural production costs, broaden the agricultural products sales channels, but not all of the network services are for agriculture-related enterprises and farmers to improve product efficiency and profitability. As the virtual market, the production, processing, marketing and other aspects of the participants do not fully understand the actual situation of farmers, some of its practices will inevitably affect the circulation of agricultural products adversely affected.

\subsection{Integration of Information Resources.}

The development of agricultural e-commerce must first pay attention to agricultural production and marketing of each link in the process of information sharing. As the dispersion of agricultural production and market asymmetry, tend to give its purchase, sale, circulation and other links on a lot of inconvenience. For the industry sector, to speed up the development of agricultural information standards, integration of agricultural and rural market information resources, we need to establish agricultural market information database, to promote the sharing of resources to share, smooth flow of information channels in rural areas. In areas with better economic conditions, agricultural products processing and marketing enterprises and farmers as well as farmers and farmers can work closely to establish a network information infrastructure to improve all aspects of the level of automation management.

\subsection{Focus on Regional Development}

Regional characteristics of agricultural e-commerce is mainly reflected in the geographical environment of customer consumption. Generally speaking, for each local specific eating habits, folk customs and cultural characteristics, you need to combine the actual agricultural e-commerce enterprises, to develop and cultivate new, distinctive agricultural products and services. And according to the target area of sales radius differences, agricultural e-commerce enterprises should also gradually improve and upgrade their distribution system. In addition, the development of agricultural e-commerce, but also the need to strengthen the construction of agricultural brand 
personality and research and development, to explore the design, production and processing of some similar "Chu orange, Liu Tao, Pan apple" high-end agricultural special products to enhance themselves Of the value-added products to meet the various fields, the needs of different groups.

\subsection{Strengthen the Logistics System}

Logistics and distribution is an important part of e-commerce. As agricultural products and raw materials are prone to rot, mildew and pests and other characteristics, different customers to order the demand for agricultural products is also a variety of time. Which makes the distribution of agricultural products in the link than the average consumer goods logistics requirements. On the other hand, it is necessary to strengthen the construction and operation of the internal logistics and distribution departments of agricultural e-commerce enterprises, and to build large-scale well-known logistics enterprises in the agricultural product logistics system construction process, on the one hand, to focus on the integration of logistics resources, the establishment of specialized and socialized agricultural logistics enterprises; Enterprises or leading enterprises to support the establishment of the industry, the region's distribution service site. At the same time, the local government should also timely planning, to build a number of integrated sorting distribution center, in order to effectively promote the local agricultural products circulation, sales and transactions.

\subsection{Establish Win-win Goal}

E-commerce to the contemporary people's production, lifestyle changes, the development of agricultural e-commerce starting point and destination should be in the "farmers' income, consumers benefit." The majority of farmers through e-commerce platform will be local high-quality agricultural products to sell to local markets, to reduce transaction costs, increase farmers' income, the development of rural economy; consumer through e-commerce platform, not only to a wider range of agricultural products, So that the purchase of agricultural products more fresh and rest assured. In the future development of agricultural e-commerce process, we must focus on doing three aspects: First of all, the average farmer or agricultural production enterprises, as far as possible to improve the quality of agricultural products, in order to ensure its sales and benefits; Second, the sales of agricultural products or ordinary consumers, through e-commerce platform to complete the convenient ordering and payment of agricultural products to meet their own personalized and sharing needs; Finally, to ensure the smooth flow of agricultural information, the basic balance of supply and demand of agricultural products, agricultural e-commerce parties to effectively benefit.

\section{Conclusions}

"Internet + " represents the new direction, new path and new impetus of modern agricultural development. From the flourishing electricity supplier to flourishing, to the agricultural power of the other businesses, and then to the leisure agricultural electricity business wind and water, the development of China's agricultural e-commerce has become a beautiful e-commerce landscape. It can be said that agricultural e-commerce is the industrialization of agriculture and information technology to agricultural modernization of the necessary stage, it is the world's agriculture, especially in developing countries and regions of agriculture has brought unprecedented opportunities for development. In this paper, we analyze and compare several typical patterns of agricultural e-commerce. It is important to note that only from the actual situation of farmers or agricultural enterprises and their own needs, combined with their size, technology, capital, human resources and transportation resources Conditions, in order to find its agricultural e-commerce model construction principles or standards in order to enable farmers and agricultural enterprises in the Internet transaction process to obtain greater profits, so as to promote the development of China's agricultural economy leap. The section headings are in boldface capital and lowercase letters. Second level headings are typed as part of the succeeding paragraph (like the subsection heading of this paragraph).

\section{References}


[1] Qin Zheng. E-commerce Introduction (third edition) [M]. Beijing: Higher Education Press, 2012.

[2] Li Ning, Pan Xiao, Xu Yingqi. Internet + agriculture: help traditional agricultural transformation and upgrading [M]. Beijing: Mechanical Industry Press, 2015.

[3] Ali Research Institute. China Taobao Village [M]. Beijing: Electronic Industry Press, 2015.

[4] Ma Di. China's agricultural e-commerce situation and development of countermeasures [D]. Xi'an: Shaanxi Normal University, 2013.

[5] Zhao Xia. Analysis of China's third-party e-commerce model of agriculture [D]. Wuhan: Central China Normal University, 2011. 